\title{
Concerns on liquid mercury and mercury-containing wastes: A review of the treatment technologies for the safe storage
}

\author{
O. Rodriguez*, I. Padilla, H. Tayibi and A. López-Delgado \\ National Centre for Metallurgical Research, CENIM, CSIC. Avda. Gregorio del Amo, \\ 8. 28040 Madrid. Spain \\ *corresponding author: olgarodriguez@cenim.csic.es
}

\begin{abstract}
Due to the adverse effects of mercury on human health and the environment, restrictive legislations and world-wide common efforts are now under way to reduce both the supply and demand of mercury. As a result, all excess $\mathrm{Hg}$ must be stored in safe conditions in secure places. This paper is an attempt to review the various treatment technologies types of liquid mercury $\left(\mathrm{Hg}^{0}\right)$ and mercury-containing wastes, which can be used to store these residues in a safe way. The different treatments were classified as a function of the waste treated. The main treatments described are amalgamation, formation of sulfides, thermal treatments, vitrification, soil washing, sulfur polymer stabilization solidification, chemically bonded phosphate ceramics and other encapsulation processes, being highlighted the stabilization/solidification processes that are the treatments that provide better results, according to the consulted bibliography.
\end{abstract}

Keywords: mercury, mercury-containing waste, safe storage, solidification/stabilization, amalgamation, encapsulation 


\section{Introduction}

Mercury occurs naturally in the environment and can be found in elemental (metallic), inorganic, and organic forms. Historically, mercury and its compounds have been used for industrial, medicinal, and cosmetic purposes. Modern uses for mercury include production of chlor-alkali, in wiring devices and switches, measuring and control devices, lighting, and dental work.

Mercury, and particularly the organic methylmercury form, is a potent neurotoxin capable of impairing neurological development in fetuses and young children and damaging the central nervous system of adults. High exposures to inorganic mercury may damage the gastrointestinal tract, the nervous system, and the kidneys. The toxicity of mercury depends strongly on its redox state (Clarkson, 1992). The most toxic form of mercury is the highly reactive $\mathrm{Hg}^{2+}$, which binds to the amino acid cysteinein proteins. In contrast, the danger of elemental mercury $\left(\mathrm{Hg}^{0}\right)$ and organo-mercury compounds lies in their transport routes (Miretzky and Fernández, 2009). Mercury vapor is easily inhaled, enters the blood stream in the lungs and is thus distributed throughout the body. Within cells, it is oxidized to reactive $\mathrm{Hg}^{2+}$. The toxicity of monomethylmercury $\left(\mathrm{MeHg}^{+}\right)$or dimethylmercury $\left(\mathrm{Me}_{2} \mathrm{Hg}\right)$ is caused by its ability to penetrate membranes within seconds and also to cross the blood-brain barrier. Symptoms of mercury poisoning are mainly neuronal disorders, but also damage to the cardiovascular system, kidney, bones, etc. (Clarkson, 1992; Sigel, 1997).

Both inorganic and organic mercury compounds are absorbed through the gastrointestinal tract and affect other systems via this route. However, organic mercury 
compounds are more readily absorbed via ingestion than inorganic mercury compounds (US EPA, 2011). People are most likely to be exposed to harmful quantities of mercury through consumption of fish contaminated with methylmercury (US EPA, 2005). Elemental mercury causes adverse health effects when it is breathed as a vapor and absorbed through the lungs. These exposures can occur when elemental mercury is spilled or products that contain elemental mercury break and expose the substance to the air, particularly in warm or poorly ventilated indoor spaces (US EPA, 2011). Exposure to inorganic mercury can also occur from drinking contaminated water and touching contaminated water and soil, though these exposures are generally not thought to be harmful at typical ambient levels (US EPA, 1999).

The three major sources of $\mathrm{Hg}$ emissions are natural, anthropogenic and re-emitted sources (US EPA, 2007). Urban discharges, agricultural materials, mining and combustion and industrial discharges are the principal anthropogenic sources of $\mathrm{Hg}$ pollution in the environment. The most important ore of mercury, cinnabar $(\mathrm{HgS})$, has been mined continuously since 415 BC. In the period before the industrial revolution, Hg was used extensively in gold extraction; in the 1800s, it was used in the chlor-alkali industry, in the manufacture of electrical instruments, and as a medical antiseptic. Since 1900, it has been used in pharmaceuticals, in agricultural fungicides, in the pulp and paper industry and in the production of plastics (Clarkson and Marsh, 1982).

Mercury undergoes complex physical, chemical and biological transformations in the environment, being the principal ones: (a) the transport of $\mathrm{Hg}^{0}$ through the atmosphere, its photochemical oxidation to reactive $\mathrm{Hg}^{2+}$ and subsequent deposition on soils, lakes, rivers and the sea; (b) the methylation of $\mathrm{Hg}^{2+}$ by reducing bacteria in anoxic habitats, 
its uptake by aquatic organisms and accumulation in the food web, resulting in high mercury concentrations in fish and chronic low level exposure of humans (WagnerDöbler, 2003). Hg contamination can be much more widespread than that observed for other metals due to atmospheric transport (Mason et al., 1994; Fitzgerald et al., 1998) or to biomagnification through the food chain, reaching fish and humans (Mason et al., 1996).

The following mercury compounds are most frequently found under environmental conditions: mercuric salts $\mathrm{HgS}, \mathrm{HgCl}, \mathrm{Hg}(\mathrm{OH})$ and $\mathrm{HgS}$; the methylmercury ion $\left(\mathrm{HgCH}_{3}{ }^{+}\right)$and its compounds methylmercuric chloride $\left(\mathrm{CH}_{3} \mathrm{HgCl}\right)$ and methylmercuric hydroxide $\left(\mathrm{CH}_{3} \mathrm{HgOH}\right)$; and, in small fractions, other organomercurics (for example, dimethylmercury and phenylmercury) (MADEP, 1996; US EPA, 1997a) Methylmercury is formed when mercury enters soil or sediments and is acted on by anaerobic microorganisms (US EPA, 2011). The solubility of mercury compounds ranges from negligible $(\mathrm{HgCl}, \mathrm{HgS})$ to very soluble $\left(\mathrm{HgCl}_{2}\right)$ (MADEP, 1996).

Table 1 shows some characteristics of the main mercury compounds (US EPA, 2007; Handbook of Mineralogy, 2011; Lide, 2005).

Table 1. Characteristics of mercury compounds (Addapted from US EPA, 2007)

\begin{tabular}{|c|c|c|c|c|c|c|}
\hline $\begin{array}{l}\text { Compound } \\
\text { name }\end{array}$ & $\begin{array}{l}\text { Elemental } \\
\text { Mercury }\end{array}$ & $\begin{array}{l}\text { Mercuric } \\
\text { sulphide }\end{array}$ & $\begin{array}{l}\text { Mercuric } \\
\text { chloride }\end{array}$ & $\begin{array}{l}\text { Mercurous } \\
\text { Chloride }\end{array}$ & $\begin{array}{l}\text { Methyl- } \\
\text { mercuric } \\
\text { Chloride }\end{array}$ & $\begin{array}{l}\text { Dimethyl } \\
\text { Mercury }\end{array}$ \\
\hline $\begin{array}{l}\text { Molecular } \\
\text { formula }\end{array}$ & $\mathrm{Hg}^{0}$ & $\mathrm{HgS}$ & $\mathrm{HgCl}_{2}$ & $\mathrm{Hg}_{2} \mathrm{Cl}_{2}$ & $\mathrm{CH}_{3} \mathrm{HgCl}$ & $\mathrm{C}_{2} \mathrm{H}_{6} \mathrm{Hg}$ \\
\hline $\begin{array}{l}\text { Molecular } \\
\text { weight }\end{array}$ & 200.59 & 232.66 & 271.52 & 472.09 & 251.1 & 230.66 \\
\hline \multirow{2}{*}{$\begin{array}{c}\text { Solubility } \\
(\mathrm{g} / \mathrm{l}) \\
\left(\text { in } \mathrm{H}_{2} \mathrm{O}\right)\end{array}$} & \multirow{2}{*}{$\begin{array}{l}5.6 \times 10^{-5} \\
\left(25^{\circ} \mathrm{C}\right)\end{array}$} & $\begin{array}{c}\text { Cinnabar: } \\
2 \times 10^{-53}\left(25^{\circ} \mathrm{C}\right)\end{array}$ & \multirow{2}{*}{$\begin{array}{c}69 \\
\left(20^{\circ} \mathrm{C}\right)\end{array}$} & \multirow{2}{*}{$\begin{array}{l}2.0 \times 10^{-3} \\
\left(25^{\circ} \mathrm{C}\right)\end{array}$} & \multirow{2}{*}{$0.100\left(21^{\circ} \mathrm{C}\right)$} & \multirow{2}{*}{$\begin{array}{c}1 \\
\left(21^{\circ} \mathrm{C}\right)\end{array}$} \\
\hline & & $\begin{array}{l}\text { Metacinnabar: } \\
2 \times 10^{-32}\left(25^{\circ} \mathrm{C}\right)\end{array}$ & & & & \\
\hline Density & 13.53 & Cinnabar: & 5.40 & 7.15 & 4.06 & 3.19 \\
\hline
\end{tabular}




\begin{tabular}{|c|c|c|c|c|c|c|}
\hline$\left(\mathrm{g} / \mathrm{cm}^{3}\right)$ & $\left(25^{\circ} \mathrm{C}\right)$ & $\begin{array}{c}8.17\left(25^{\circ}\right) \\
\text { Metacinnabar: } \\
7.70\left(25^{\circ} \mathrm{C}\right)\end{array}$ & $\left(25^{\circ} \mathrm{C}\right)$ & $\left(19^{\circ} \mathrm{C}\right)$ & $\left(20^{\circ} \mathrm{C}\right)$ & $\left(20^{\circ} \mathrm{C}\right)$ \\
\hline $\begin{array}{c}\text { Boiling } \\
\text { Point }\left({ }^{\circ} \mathrm{C}\right)\end{array}$ & 357 & Not available & 302 & 384 & Not available & 93 \\
\hline $\begin{array}{c}\text { Melting } \\
\text { Point }\left({ }^{\circ} \mathrm{C}\right)\end{array}$ & -39 & $\begin{array}{c}\text { Cinnabar: } \\
\text { Transform to } \\
\text { metacinnabar } \\
\text { at } 344 \\
\text { Metacinnabar: } \\
850\end{array}$ & 277 & 302 & 170 & -43 \\
\hline $\begin{array}{c}\text { Oxidation } \\
\text { State }\end{array}$ & 0 & +2 & +2 & +1 & +2 & +2 \\
\hline
\end{tabular}

Ionic forms of mercury are strongly adsorbed by soils and sediments and are desorbed slowly. Clay minerals optimally adsorb mercury ions at $\mathrm{pH} 6$, while, iron oxides adsorb mercury ions in neutral soils. Most mercury ions are adsorbed by organic matter (mainly fulvic and humic acids) in acidic soils. When organic matter is not present, mercury becomes relatively more mobile in acid soils and can evaporate to the atmosphere or leach to groundwater (MADEP, 1996).

The actual legislation about mercury (European Directive 2000/60/CE) considers mercury as a priority hazardous substance due to its adverse effects on human health and the environment, and indeed a world-wide common effort is now under way to reduce both, the supply and demand of mercury. EU Council and European Parliament Regulation, 1102/2008 (EC) set 2011 as the cutoff date for industrial use of $\mathrm{Hg}$ and the banning of mercury exports and addresses the issue of safe storage of metallic mercury. The export ban came into force on 15 March 2011 and affects metallic mercury, cinnabar ore, mercury (I) chloride, mercury (II) chloride, and mixtures of metallic mercury with other substances, including mercury alloys (EU Council and European Parliament Regulation, 636/2006). As a result, all excess Hg must be stored in safe 
conditions and in secure places until definitive stabilization policies are established (López et al., 2010)

There is a huge variety of described technologies that deal with the problem of the safely storing of liquid $\mathrm{Hg}^{0}$ and mercury wastes, and this review aims to highlight the most representative ones. The technologies will be classified according to the nature and/or origin of the waste in $\mathrm{Hg}^{0}$ treatments and solid waste treatments.

However, there are specific technologies that not attend to the nature/origin of the waste, besides the fact that these are the most employed technologies, and this review attempts to highlight them, thus the stabilization/solidification technologies will be described in a separate section.

\section{Liquid mercury treatments}

Most of the treatments available for liquid mercury $\left(\mathrm{Hg}^{0}\right)$ are based on the formation of sulfides and on amalgamation. In the case of the reaction with sulfur, various authors consider it as an amalgamation process (i.e. US5034054, 1991), however, combining mercury with sulfur results in mercuric sulfide. $\mathrm{HgS}$ is not an amalgam or alloy, and accordingly, the technologies for the formation of sulfides will be considered separately.

\subsection{Amalgamation}

The amalgamation is a chemical process unique to elemental mercury, in which another metal forms a semisolid alloy "amalgam" with mercury. Mercury dissolves in the solid metal, forming a solid solution. The process is reversible, so that mercury can be 
released from these alloys by heating. Amalgams, although solid, show a significant vapor pressure and solubility of mercury (GRS, 2009).

They are solid but sometimes quite soft or paste-like materials. In some processes amalgamation is used as a stabilization technique. Then mercury is mixed with a metal powder (mostly zinc or copper) to give the solid amalgam, e.g.:

$$
\mathrm{x} \mathrm{Hg}(1)+\mathrm{y} \mathrm{Cu} \rightarrow \mathrm{Cu}_{\mathrm{y}} \mathrm{Hg}_{\mathrm{x}}
$$

The process designed by Ecoflo (USA) consists on putting liquid mercury in a disposable bottle or container and mix it with a powdered amalgamating agent in ratio of $1: 1$ to $1: 3$. Proposed agents are copper, nickel or zinc. Shaking is performed by means of a paint mixer for at least 5 - 15 minutes, but 40 minutes for metals powders are recommended (US5034054, 1991).

In the Institute of Gas Technology (USA), the powdered copper is cleaned from oxides and other compounds by immersing it into diluted hydrochloric acid/ammonium chloride or by heating it at $500-700{ }^{\circ} \mathrm{C}$ in hydrogen gas. Mercury is added $(50-80 \mathrm{wt} \%$ in the final mixture) and the resulting mixture is agitated, as consequence, a slurry that hardens at ambient temperature within a day or two is produced (GRS, 2009).

Gorin et al. (1994) proposed a copper amalgam, the procedure consists on washing fine copper powder (325 mesh) with nitric acid and then milled it in a laboratory shaker with stainless steel balls. Elemental mercury is added so that the mixture contains $65 \mathrm{wt} \%$ mercury. The mixture is milled for 45 minutes and the resulting paste is then stirred, 
milled for other 45 minutes, hardened and then crushed into a powder, if necessary. The same authors proposed also a zinc amalgam, the fine zinc powder (325 mesh) is washed with nitric acid and then milled in a laboratory shaker with stainless steel balls (Gorin et al., 1994). Elemental mercury is added so that the mixture contains $45 \mathrm{wt} \%$ mercury. This mixture is milled for $2 \mathrm{~h}$. The obtained amalgam with zinc does not comply the TLCP test (maximum $\mathrm{Hg}$ concentration=0.2 ppm, Land Disposal Restrictions Regulations for Mercury-Containing Non-wastewaters), so it can not be considered as an adequate technique.

In amalgamation process, the vapor pressure obtained in the amalgam is similar than the obtained for elemental mercury, which makes this technique by itself insufficient to immobilize the mercury, but it can be used as complementary technique, together with another immobilization process (BiPro, 2010).

\subsection{Formation of sulfides and selenides of $\mathrm{Hg}$}

Processes that implement this approach often start with elemental mercury $-\mathrm{Hg}(1)$ that reacts with elemental sulfur or with other sulfur-containing substances like thiosulfate or pyrite $\left(\mathrm{FeS}_{2}\right)$ to mercury sulfide (GRS, 2009):

$$
\mathrm{Hg}(1)+\mathrm{S} \rightarrow \mathrm{HgS}
$$

The conversion into mercury sulfide can be achieved by mixing solid sulfur with liquid mercury, by dissolving mercury in liquid sulfur or in a gas phase reaction between 
gaseous mercury and gaseous sulfur. At room temperature, solid mercury sulfide exists on two kinetically stable modifications (Table 2):

Table 2. Characteristics of $\alpha-\mathrm{HgS}$ (cinnabar) and $\beta-\mathrm{HgS}$ (metacinnabar)

\begin{tabular}{|c|c|c|c|}
\hline & & $\begin{array}{c}\alpha-\mathrm{HgS} \\
\text { cinnabar }\end{array}$ & $\begin{array}{c}\beta-\mathrm{HgS} \\
\text { metacinnabar }\end{array}$ \\
\hline \multicolumn{2}{|l|}{ Colour } & red & black \\
\hline \multicolumn{2}{|c|}{ Crystal system } & hexagonal & cubic \\
\hline \multicolumn{2}{|c|}{ Structure type } & cinnabar & sphalerite \\
\hline \multicolumn{2}{|l|}{$Z$} & 3 & 4 \\
\hline \multicolumn{2}{|l|}{$\mathrm{a}(\AA)$} & 4.149 & 9.495 \\
\hline \multicolumn{2}{|l|}{$\mathrm{c}(\AA)$} & 5.8517 & - \\
\hline \multicolumn{2}{|c|}{ Hardeness } & 2.3 & 3.0 \\
\hline \multirow{3}{*}{$\begin{array}{l}\text { Index of } \\
\text { refraction }\end{array}$} & $\mathrm{n}_{\alpha}$ & 2.814 & - \\
\hline & $\mathrm{n}_{\beta}$ & 3.143 & - \\
\hline & $\mathrm{n}_{\gamma}$ & - & - \\
\hline \multicolumn{2}{|c|}{$\Delta \mathrm{H}_{\mathrm{f}}^{0}(\mathrm{~kJ} / \mathrm{mol})$} & -58.10 & -53.50 \\
\hline \multicolumn{2}{|c|}{$\Delta_{\mathrm{t}} \mathrm{G}_{\mathrm{f}}^{0}(\mathrm{~kJ} / \mathrm{mol})$} & -50.58 & -47.65 \\
\hline \multicolumn{2}{|c|}{$\mathrm{C}_{\mathrm{p}}(\mathrm{J} / \mathrm{molK})$} & 48.4 & - \\
\hline
\end{tabular}

The latter is thermodynamically slightly less stable, but it is the principle product of reactions in a very broad temperature range. Both compounds are only very slightly soluble in water.

An also quite insoluble compound is mercury selenide that is formed from elemental mercury and selenium:

$$
\mathrm{Hg}(\mathrm{l})+\mathrm{Se} \rightarrow \mathrm{HgSe}
$$

$\mathrm{HgSe}$ is also known under its mineral name Tiemannite. Mercury selenide cannot be synthesized by mixing the elements at room temperature. Therefore, either a gas phase reaction or a reaction in aqueous media, after oxidation of $\mathrm{Hg}(0)$ to $\mathrm{Hg}(\mathrm{II})$, is required.

In bibliography, a variety of processes using this technique for the stabilization of liquid mercury can be found. These processes differ from each other by the temperature, 
pressure and ratio of reagents employed. In the case of the process developed by DELA (Germany), elemental sulfur is vaporized in a heated vacuum mixer and reacts in the gas phase with added elemental mercury to form mercury sulfide. The process utilizes a vacuum mixer, a device that is also being employed at DELA to treat different types of mercury-containing waste. First the vacuum mixer is flooded with nitrogen in order to replace any oxygen in the system that might oxidize mercury or sulfur. A vacuum $(<0.9$ bar) is applied and the necessary amount of sulfur is added ( $\mathrm{S}: \mathrm{Hg}$ ratio between $0.16: 1$ to $0.32: 1$ ). The mixer is heated to a temperature higher than the boiling temperature of mercury $\left(>580^{\circ} \mathrm{C}\right)$. Then mercury is added over a period of time. Unlike processes at lower temperature a nearly stoichiometric ratio between mercury and sulfur can be used. Due to the high temperature employed, within several seconds mercury completely reacts with the gaseous sulfur to form mercury sulfide. Afterwards, mixing is continued for a defined time and the still gaseous mercury sulfide can be condensed by cooling down the gas phase. The process can be operated in batch mode as well as in continuous mode. The final product is a mixture of black metacinnabar $(\beta-\mathrm{HgS})$ and red cinnabar $(\alpha-\mathrm{HgS})$. A pilot plant has been operated batch-wise with a capacity of $500 \mathrm{~kg}$ per day. The maximum treatment capacity will be in the range of 3 to $6 \mathrm{t}$ per day (DE102008006A1, 2009; US7914757, 2011).

Traditionally, mercury (II) sulfide generation technologies have relied on physically mixing or blending elemental mercury with sulfur at relative low temperatures, and these technologies fail to completely purge residual elemental mercury from mercury (II) sulfide (US7691361B1, 2010). In the treatment, patented by Bethelem apparatus Company (USA), the reaction between elemental mercury and sulfur takes place under high temperature and pressure conditions and creates a more stable and less soluble form of mercury (II) sulfide (cinnabar). The ratio sulfur/elemental mercury (by weight) 
is between about 0.168 and 0.176 (US7691361B1, 2010). The material obtained is equal, in its physical and chemical properties, to naturally occurring cinnabar. According to the company information, the produced mercury sulfide did not show any trace of elemental mercury and headspace analyses also, confirmed the absence of mercury in the gas phase (GRS, 2009). The operating system will be capable of processing 500 to $1000 \mathrm{~kg}$ of mercury per day (BiPro, 2010).

In the process built up by STMI (France), liquid mercury and elemental sulfur react in a glass apparatus by stirring the mixture at elevated temperature. The process employs a molar $\mathrm{Hg} / \mathrm{S}$ ratio of $1: 1$ to $1: 3$. Both reactants are poured into the round-bottom flask of an apparatus consisting of a motor, an axial glass pipe and a rotatable axial flask. Stirring is accomplished by rotating the flask, preferably at $50 \mathrm{rpm}$ for 2 hours (higher speed gave slower reaction rates). Reaction already takes place at $20{ }^{\circ} \mathrm{C}$ but heating to $60-80{ }^{\circ} \mathrm{C}$ is preferred. Application of even higher temperatures (e.g. $360{ }^{\circ} \mathrm{C}$ ) enables the distillation and purification of mercury itself. Mercury is then collected in a receiver that subsequently can be employed to act as a reactor also. The product obtained is a finely grained black powder, identified as a mixture of metacinnabar and sulfur. According to available information, the method in its semi-pilot stage is limited to batches with $1 \mathrm{~kg}$ mercury (US7560087B2, 2009).

The process patented by CSIC (Spain) (P200930672, 2009) and developed in a LIFE project MERSADE, consists on convert the elemental mercury to mercury sulfide by milling at room temperature. Equal weight amounts of mercury and sulfur (according to a stoichiometric excess of $45 \mathrm{wt} \%)$ were brought to reaction in a planetary ball mill containing stainless steel balls The impact and friction forces of milling on the $\mathrm{Hg}$ and $\mathrm{S}$ 
mixture resulted in the formation of metacinnabar by reducing the size of mercury drops, giving rise to microspheres, and lowering the surface tension to allow sulfur grains to become adhered at the reaction interface. Milling was done at $400 \mathrm{rpm}$ for 15 minutes to 3 hours. After 60 min of milling, the metacinnabar formation reaction was observed to be more than $99.99 \%$ complete. The TCLP test on this sample yielding values of $3.1 \mu \mathrm{g} / \mathrm{L} \mathrm{Hg}$. Thus the final product complies with the limits of the most stringent Universal Treatment Standard requirements, which allow a maximum TCLP concentration of $25 \mu \mathrm{g} / \mathrm{L}$ (López et al., 2010).

The formation of sulfides and selenides greatly improves the solubility with respect to the elemental mercury; however complementary processes as the stabilization/solidification with sulfur polymer, or encapsulation technologies could contribute to a major isolation of the residue from the surrounding atmosphere. These processes will be described below.

Although the processes of stabilization of mercury, by means of the formation of sulfides and selenides, are commonly used in $\mathrm{Hg}^{0}$ waste, they have also been used in solid wastes containing large amount of mercury. Piao and Bishop (2006) tested inorganic high mercury wastes (wastes containing greater than $260 \mathrm{mg} / \mathrm{kg}$ total mercury). The addition of sodium sulfide to the mercury waste substantially reduced the amount of mercury released from the waste during leaching. It is concluded that the most effective stabilization occurred at $\mathrm{pH} 6$ combined with a sulfide/mercury molar ratio of 1 . The mercury stabilization efficiency reached as high as $99 \%$, even in the presence of interferents $\left(\mathrm{Cl}^{-}, \mathrm{PO}_{4}{ }^{3-}, \mathrm{CO}_{3}{ }^{2-}, \mathrm{Fe}^{2+}, \mathrm{Pb}^{2+}\right.$ and EDTA $)$. 


\subsection{Other treatments}

Other treatments to stabilize the liquid mercury, mainly by the use of adsorbents, are described in the bibliography. A number of them are based on activated carbon. Zhao et al., 2010, used an activated carbon obtained from modified rice husk ash (RHA) (Zhao et al., 2010). They prepared modified sorbents $\left(\mathrm{I}_{2} / \mathrm{CaO} / \mathrm{RHA}\right.$ sorbents, prepared by combustion of rice husk (RH), followed by water hydration method, to synthesized $\mathrm{CaO} /$ RHA and then impregnated with $\mathrm{I}_{2}$ to achieve the final sorbent) for $\mathrm{Hg}^{0}$ removal using a laboratory-scale fixed-bed reactor with an online total $\mathrm{Hg}$ analyzer. These sorbents exhibited effective $\mathrm{Hg}^{0}$ removal; even the lower loading sorbent $(0.6 \%$ using anhydrous ethanol) revealed initial maximum $\mathrm{Hg}^{0}$ removal efficiency of $90 \%$ under simulated flue gas including only $\mathrm{N}_{2}$ and $\mathrm{Hg}^{0}$. The physical characteristics of sorbents (surface area and pore size distribution) and iodine impregnation modes did not significantly affect $\mathrm{Hg}^{0}$ capture efficiency, while fair correlation was observed between $\mathrm{Hg}$ uptake capacity and iodine content. Therefore, the content of $\mathrm{I}_{2}$ impregnated on the sorbents is the most important factor influencing the capacity of these sorbents for $\mathrm{Hg}^{0}$ capture. The experiment under a wide range of temperature implied that chemisorptions played an important role in $\mathrm{Hg}^{0}$ removal. The benefit of this treatment lies in using a waste (RHA) to treat another one $\left(\mathrm{Hg}^{0}\right)$, being a good environmental solution. However, this kind of treatment can only be employed to treat small amounts of $\mathrm{Hg}^{0}$, besides the fact that RHA $/ \mathrm{Hg}^{0}$ must be stored and make it suitable only for particular cases nor for a global solution. 


\section{Treatments for solid waste containing mercury}

Traditionally, the main source of solid wastes of mercury has been the mercury mines (from cinnabar) (Navarro et al., 2009). The released $\mathrm{Hg}$ into the environment, in mercury mining areas, is generally associated with the abandonment of mine waste, which is mainly composed of calcines (waste originated in the metallurgy of $\mathrm{Hg}$ ) and mining wastes impoundments, which contain waste rock and low-grade stockpiles (Gray, 2003; Rytuba, 2003; Higueras et al., 2003; Fernandez-Martinez et al., 2006; Qiu et al., 2006; Navarro et al., 2006). Wastes are also generated in gold and silver mining, and chlor-alkali manufacturing, both the surrounding soil and solid waste generated during industrial activity. On the other side, a huge amount of $\mathrm{Hg}$ wastes are generated in the manufacturing of lamps, (Chang et al., 2009) especially cold cathode fluorescent lamps (CCFLs), ultraviolet (UV) lamps, and high pressure mercury lamps (SHPs), which are produced and used worldwide. These are large volumes of wastes that can be treated in different ways, the most commonly used technologies are described below which are grouped according to the type of the principal treatment employed: processes evolving heating (at low or at high temperatures) and water based technologies.

\subsection{Thermal treatment}

Thermal desorption and retorting or roasting (US EPA 2007; Federal Remediation Technologies Roundtable, 2001; Washburn and Hill, 2003) are two common ex situ methods of thermal treatment for mercury. These technologies have been used to treat mercury-contaminated soil, sediments, and wastes at full scale. Thermal treatment 
usually involves application of heat and reduced pressure to volatilize mercury from the contaminated medium, followed by conversion of the mercury vapors into liquid elemental mercury by condensation. The liquid elemental mercury collected from the condenser units can be reused or further treated, typically by amalgamation, for disposal. Off-gasses also may require further treatment. It uses heat to volatilize mercury from the contaminated medium. The main components of a thermal desorption system are a pre-treatment and material handling unit, a desorption unit, and a posttreatment unit for treatment of off-gas and processed medium (soil or waste). A typical thermal desorption unit for mercury removal operates at temperatures ranging from 320 to $700{ }^{\circ} \mathrm{C}$ (Federal Remediation Technologies Roundtable, 2001; Washburn and Hill, 2003; US EPA, 1996; US Department of Energy Office of Science and Technology, 2002).

A retorting or roasting process is similar to thermal desorption except that it does not involve agitation (The Interstate Technology \& Regulatory Council, 1998). The main components of a mercury retort system include a retort oven, condensers, a mercury trap, a sulfonated carbon adsorber, and a vacuum pump. The retort chamber typically operates at temperatures of 425 to $540{ }^{\circ} \mathrm{C}$ under a vacuum to facilitate volatilization of mercury. The resulting off-gas is passed through condensers to collect liquid elemental mercury.

Thermal desorption and retorting follow the same process, a scheme of both processes can be seen in Figure 1. This method is recommended by US EPA for wastes with contents of mercury higher than $260 \mathrm{mg} / \mathrm{kg}$ (US EPA, 2008). 
Recent studies (Busto et al., 2011) show that this treatment is very effective to remove the $\mathrm{Hg}$ from chlor-alkali industry wastes, obtaining mercury removal efficiency close to $100 \%$. Leachability according to the US EPA TCLP leaching test decreases below the threshold value of $0.2 \mathrm{mg} \mathrm{Hg} / 1$ after treatment at a temperature of $400{ }^{\circ} \mathrm{C}$ or higher (retorting time of 1 hour). Similar results were reported by Chang and Yen (2006). Also similar findings were reported by Taube et al. (2008), but in this case, working with mercury contaminated soils.

Other studies use solar energy to provide the required energy to the thermal treatment of soils, a very favorable technique from the environmental point of view. The removal of mercury from the polluted soil reached $76 \%$ using this technique (Navarro et al., 2009).

Microwave energy has also been used to achieve the optimum temperature to volatilize the mercury. Thus, Tranquila (2005) describes a process which uses microwave energy to provide the heat necessary for mercury vaporization without the need for any flame or combustion gases. The means for such process, for example a metallic fluidized bed vessel into which the mercury contaminated material is continuously fed and removed and into which microwave energy is introduced, is a compact and efficient equipment which has certain advantages over other retorts and pyrolysers (US20050089460, 2005).

Due to the high energy consumption of this type of treatment and in an attempt to reduce it, Comuzzi et al. (2011) combine this technology with a cation exchange process. Although the technology is still on development, a decreasing in the process cost is expected because of the decreasing in the temperature of treatment. 


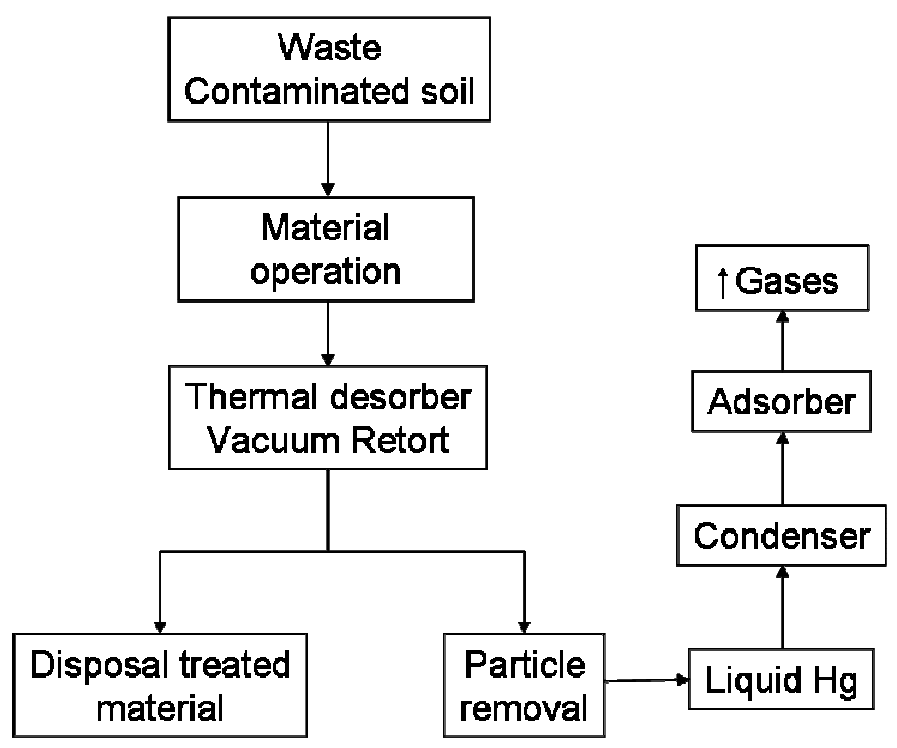

Fig. 1. Thermal desorption or retort system.

\subsection{Vitrification}

Vitrification is a high-temperature treatment technology designed to immobilize contaminants by incorporating them into the vitrified end product, which is chemically durable and leach resistant (US EPA, 1997b) (Khan et al, 2004).

There are two types of vitrification, in-situ and ex-situ. In-situ vitrification (Fig. 2) uses electrical current to heat (melt) and vitrify the treatment material in place, and it is mainly employed for the treatment of soils. An electric current is passed through the soil to be treated by an array of electrodes inserted vertically into the surface of the contaminated zone. As soil is non-conductive, a starter pattern of electrically conductive glass frit that contains graphite is placed on the soil in the paths of the electrodes (US EPA, 1997b). The temperature of the contaminated soil could reach values between 1600 and $2000{ }^{\circ} \mathrm{C}$. The presence of chlorides, fluorides, sulfides, and sulfates may 
interfere with the process, resulting in higher mobility of mercury in the vitrified product.

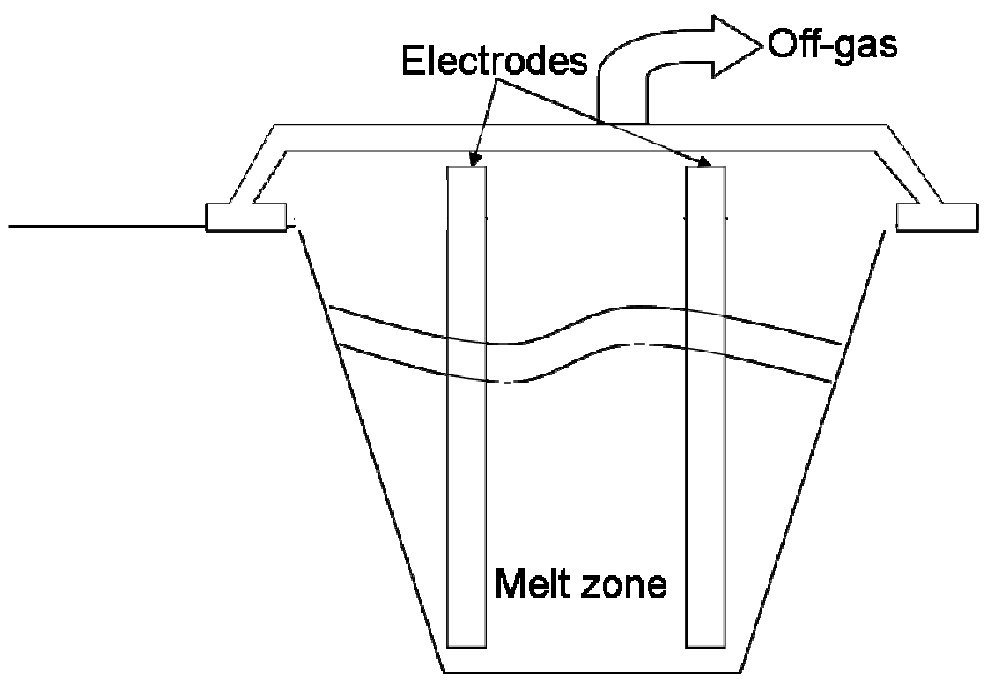

Fig. 2. In-situ vitrification system (Addapted from US EPA, 2007).

Ex-situ vitrification involves the heating of contaminated material in a melter or furnace. Two processes have been employed to treat solid wastes containing mercury: the Glass Furnace Technology (GFT) (US EPA, 2004) and the Plasma Hearth Process (US EPA, 1998). The patented GFT process uses a dryer to reduce the moisture content in the waste feed to below 10 percent (US EPA, 2004). The dried feed is mixed with a flux material to control melting temperatures and improve the physical properties of the glass aggregate product. It is then fed to the furnace. Oxygen and natural gas are combusted in the furnace to raise its internal temperature to about $1600{ }^{\circ} \mathrm{C}$. The molten material is quickly cooled in a water-quench system to form a glass aggregate product.

The Plasma Hearth Process uses an electric arc to melt non-combustible inorganic material and volatilize and oxidize organic materials (US EPA, 1998). Of course, the use of a drier, to eliminate the moisture, and the addition of fluxes are also required. Figure 3 shows a typical ex situ vitrification system. 


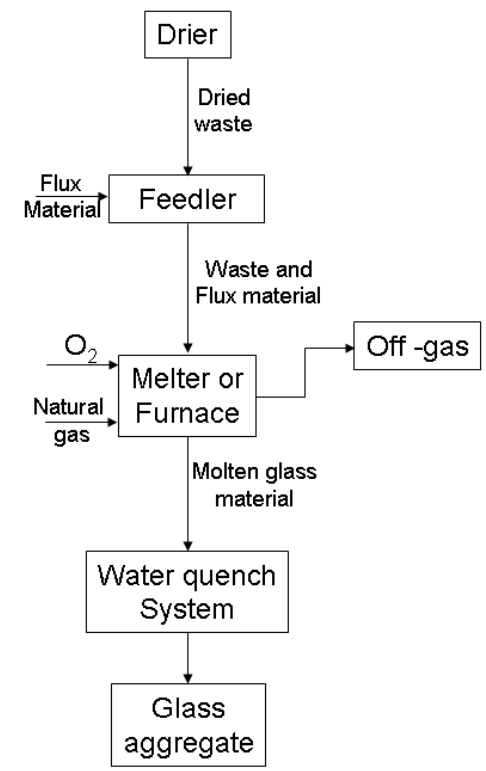

Fig. 3. Ex-situ vitrification system (Addapted from US EPA, 2007).

The use of vitrification technologies for the treatment of contaminated land, involves changes in the morphology and chemical-physical properties of the soil, so it is necessary to asses the impact that such treatment could have on soil properties, once decontaminated.

Huang et al. (2011) showed that thermal decontamination at temperature $>400{ }^{\circ} \mathrm{C}$ can lower the $\mathrm{Hg}$ content to the regulation level. The effectiveness of thermal decontamination was less affected by the $\mathrm{Hg}$ fractionation when heating at this temperature. Thermal decontamination via an oxygen-lean, indirect-heating approach was shown to have a slight effect on the texture and organic carbon content of soil samples. However, thermal decontamination caused repartitioning of metals. Heavy metals in Fe/Mn oxides transformed into acid-extractable, organic-matter bound and residual forms after thermally treated at $550{ }^{\circ} \mathrm{C} ; \mathrm{Cr}, \mathrm{Cu}$, and $\mathrm{Ni}$ became less mobilized and difficult to extract, which may greatly affect the effectiveness of subsequent 
decontamination approaches, such as acid washing or chemical extraction. Authors suggested that removal of heavy metals, via acid washing or chemical extraction, should be done before thermal treatment for $\mathrm{Hg}$ removal to achieve the greatest removal of all the heavy metals presenting in the contaminated soils.

\subsection{Soil washing}

Soil washing is a water-based technology that uses a combination of physical particle size separation and aqueous-based chemical separation methods to reduce contaminant concentrations in soil. It is based on the concept that most contaminants tend to bind to the finer soil particles (clay and silt) rather than the larger particles (sand and gravel). Physical methods can be used to separate the relatively clean larger particles from the finer ones because the finer particles are attached to larger particles through physical processes (compaction and adhesion). This process thus concentrates the contamination bound to the finer particles for further treatment.

Soil washing technology is best suited to treat contaminated soil composed primarily of larger-grained particles such as sand and gravel, rather than fine-grained particles such as clay and silt. It is also best suited to treat contaminants that preferentially adsorb onto the fines fraction. An advantage of soil washing is that it can be used to reduce the volume of material that will require further treatment, which potentially lowers the cost of cleanup and disposal of the contaminated material. Soil washing may not be costeffective for small quantities of contaminated material. This treatment is usually performed at the site of the contamination, avoiding the risks associated with transporting the contaminated soil off-site to a treatment facility. Chemicals are seldom 
released from the soil washing process to the air. When the procedure is properly designed and operated, soil washing is relatively safe (US EPA 2007).

According to Dermont et al. (2008), soil washing is a technology particularly relevant for the remediation of metal-contaminated soils. The majority of projects are based on physical separation methods which are cost effective and well established technologies in the mineral processing industry. From the economic and environmental point of view, soil washing may be an effective alternative to stabilization/solidification and landfilling. The soil washing technology presents many advantages: (1) the processes attempt to remove permanently metals from soils and can allow recycling of metal in certain cases; (2) the volume of contaminated soil is markedly reduced; (3) the processed soil can be returned to the site; and (4) the process duration is typically short to medium-term, compared to other metal extraction methods. Soil washing can be used independently or in conjunction with other treatment technologies. Despite being frequently used in Europe, the soil washing method has not been used extensively in the USA nor in Canada. Soil washing has been performed successfully in Europe, due in part to regulatory actions taken to drastically restrict landfilling options. The soil washing technology is often used for reducing the volume of soils and residues placed in landfills. Soil washing in Europe is mostly performed in fixed facilities, while mobile soil washing plant appears to be more common in the USA and Canada.

\section{Stabilization/Solidification (S/S)}

Stabilization is a chemical method which attains to the chemical immobilization by the formation of stable compounds or water-nonsoluble compounds. Stabilization reduces 
or eliminates the possibility of vaporization or leaching to the environment. To stabilize means to convert to a solid, hard, non-flowable mass or a solid and inert particulate material which resists common solvents and retains the materials contained therein, when subjected to leaching conditions.

Solidification is used to encapsulate or absorb the waste, forming a solid material, when free liquids other than elemental mercury are present in the waste. To encapsulate means to embed within a stable matrix. Molten and casting are part of the encapsulation process. The objective of these methods is to seal the waste from the surrounding environment.

Encapsulation technologies are based primarily on solidification processes that act to substantially reduce surface exposure to potential leaching media, and can also involve a combination of physical entrapment through solidification and chemical stabilization through precipitation, adsorption or other interactions (Randall and Chattopadhyay, 2004). Waste can be encapsulated in two ways: microencapsulation and macroencapsulation. Microencapsulation is the process of mixing the waste with the encasing material before solidification occurs. Macroencapsulation refers to the process of pouring the encasing material over and around the waste mass, thus enclosing it in a solid block (Chattopadhyay and Condit, 2002).

There are a large number of processes of encapsulation of elemental mercury and mercury waste, classified depending on the encasing material, such as Portland cement, sulfur polymer cement (SPC), sulfide and phosphate binders, cement kiln dust, polyester resins, or polysiloxane compounds to create a slurry, paste, or other semi- 
liquid state, which is allowed time to cure into a solid form. (US EPA, 2007), these processes will be described below. In the majority of the processes described there is no chemical reaction between the encasing material and the mercury, and therefore a stabilizing pre-treatment step would be necessary.

Although most of the processes described in the literature consist principally of combined technologies, and their classification in clearly differentiated groups involves a number of difficulties, an attempt to classification based on highlight the most employed techniques is presented in this paper.

\subsection{Sulfur Polymer Stabilization Solidification (SPSS)}

The Sulfur Polymer Stabilization Solidification (SPSS) process is based on the sulfur stabilization with the advantage that, in the case of SPSS, the final product is monolithic with a low surface area. This improves the vapor and leaching performance of the product (BiPro, 2010).

SPSS is a modification of sulfur stabilization. Within this process elemental mercury reacts with sulfur to form mercury (II) sulfide. Simultaneously, the $\mathrm{HgS}$ is encapsulated and thus the final product is a monolith. The process relies on the use of $\sim 95 \mathrm{wt} \%$ of elemental sulfur and $5 \%$ of organic polymer modifiers also called sulfur polymer cement (SPC). The SPC can be dicyclopentadiene or oligomers of cyclopentadiene. The process has to be carried out at a relatively high temperature of about $135{ }^{\circ} \mathrm{C}$, which may lead to some volatilization and thus emission of the mercury during the process. In 
any event, the process requires the provision of an inert atmosphere in order to prevent the formation of water soluble mercury (II) oxide.

In the case of SPC, $\beta-\mathrm{HgS}$ is obtained. The addition of sodium sulfide nonahydrat results in $\alpha-\mathrm{HgS}$ as a product. A relatively high $\mathrm{Hg}$ load of the monolith $(\sim 70 \%)$ can be achieved with this process, as there is no chemical reaction of the matrix required to set and cure. The process is robust and relatively simple to implement and the resulting product is very insoluble in water, has a high resistance to corrosive environment, is resistant to freeze-thaw cycles and has a high mechanical strength. During the process, volatile losses are liable to occur and therefore, appropriate engineering controls are needed. Engineering controls to avoid possible ignition and explosions are also necessary.

Additionally, the volume of the resulting waste material is considerably increased. Polysulfide is added to elemental mercury and sulfur in order to obtain a monolithic product, but the synthesis of a mercury polysulfide complex with higher leaching value, compared to mercury sulfide, shall be avoided. This can be done by adding the sulfur first and in a second step the sulfur polymer. Formation of mercury polysulfide can also be avoided by adding a polysulfide inhibitor.

The generation of toxic $\mathrm{H}_{2} \mathrm{~S}$ can be inhibited by limiting the exposure of the stabilizing inorganic sulfur compounds to air and sunlight or by adding antioxidants.

This process is used in bibliography for different types of wastes: elemental mercury (López-Delgado et al., 2011a), mercury contaminated with radionuclides, (Fuhrmann et al. 2002), contaminated soils (López et al., 2009a), etc. Studies about monoliths 
durability, concluded that the obtained $\mathrm{HgS}-\mathrm{S}$-concrete exhibits excellent mechanical properties, extremely low water absorption by capillarity, very high impermeability and high durability in different aggressive environment conditions (alkaline medium, salt mist, freeze-thaw cycles) (López et al., 2009b, López-Delgado et al., 2011b).

Different patents described the use of SPSS technology for the treatment of mercury and mercury-containing wastes, both in USA (US6399849B1, 2002; US5678234, 1997; US6403044B1, 2002) and Europe (P200930672). Several additives e.g. sodium sulfide, sulfide and calcium phosphine triisobutyl polysulfide are used to decrease the content of mercury in the leachates. In the process described in patent US20100312036, a solidification process with paraffin is employed after the sulfur stabilization.

\subsection{Chemically bonded phosphate ceramics}

In this case, the stabilization of mercury as sulfide is followed by subsequent solidification in a phosphate matrix. Powdered calcined magnesium oxide $(\mathrm{MgO})$ and potassium dihydrogen phosphate $\left(\mathrm{KH}_{2} \mathrm{PO}_{4}\right)$ are blended in equal molar amounts (GRS, 2009). Additional ingredients like fly ash or potassium (sodium sulfide (0.5 wt \%) are added and all components together with water mixed with the waste for approx. 30 minutes. $\mathrm{MgO}$ and $\mathrm{KH}_{2} \mathrm{PO}_{4}$ react to form solid and insoluble $\mathrm{MgKPO}_{4} \bullet 6 \mathrm{H}_{2} \mathrm{O}$. Afterwards, the mixture is allowed to set. Setting occurs in approximately $2 \mathrm{~h}$ while curing needs about two weeks (Wagh et al., 2000). The process has been tested for a wide range of wastes including evaporator residues, contaminated soils, various salts, wastes, small homogenous debris wastes, wastewater residues, sludges from uranium ore processing operations, incinerator ash, and spent incinerator scrub solutions, 
including elemental mercury. The waste load in the final product is up to $70 \mathrm{wt} \%$, depending on the type of waste (Chattopadhyay, 2003; US DOE ,1999).

Chemically bonded phosphate ceramics (CBPCs) are fabricated by an acid-base reaction between calcinated magnesium oxide $(\mathrm{MgO})$ and mono-potassium-phosphate $\left(\mathrm{KH}_{2} \mathrm{PO}_{4}\right)$ in solution to form a hard dense ceramic of magnesium potassium phosphate hydrate. For this purpose calcinated magnesium oxide powder and monopotassium phosphate are stirred under an aqueous condition to produce magnesium potassium phosphate (MKP). In a second step, the MKP is combined with the mercury. The process temperature is lower than $80^{\circ} \mathrm{C}$ and therefore, little hazardous off-gasses arise and no secondary waste is generated.

CBPC treatment of elemental mercury will form low solubility chemical bonded phosphate solids $\left(\mathrm{Hg}_{3}\left(\mathrm{PO}_{4}\right)_{2}\right)$, but a further improved stabilization by forming $\mathrm{HgS}$ in a first step, can be realized with a small amount of sodium sulfide $\left(\mathrm{Na}_{2} \mathrm{~S}\right)$ or potassium sulfide $\left(\mathrm{K}_{2} \mathrm{~S}\right)$. The sulfides significantly improve the performance of the final CBPC waste and are therefore recommended. An excess of sulfide will increase the leachability and therefore, careful processing is needed.

The product of the CBPC process can have a mercury load as high as $78 \%$ with a density of $1.8 \mathrm{~g} / \mathrm{cm}^{3}$. The immobilization is a result of chemical stabilization and a physical encapsulation (solidification). An advantage for phosphate glass is the high physical stability (BiPro, 2010). 
The stabilization/solidification of this phosphate ceramic could be improved by adding ground granulated blast furnace slag (GGBFS) (Liu et al., 2008). The addition of

GGBFS significantly reduced $\mathrm{Hg}^{2+}$ leaching concentration and enhanced compressive strength of mercury-doped CBPC matrixes, made the pore structure of mercury doped CBPC matrixes finer by reducing its critical pore size, could also refrain from the reaction temperature rise of matrix to prevent the volatilization of mercury, and both physical filling of GGBFS and microencapsulation of cementing gel were responsible for less leaching and better physical performances of mercury-doped CBPC matrixes.

\subsection{Other encapsulation technologies}

The technologies involving encapsulation with other binders, such as Portland cement, asphalt and resins, will be described next. These technologies are not as widely used as sulfur polymer and ceramic phosphates.

\subsubsection{Cement mixtures}

The high strength, low permeability and relatively high durability of hydraulic cement make it a good binder for this waste management technique; however heavy metals, as mercury, often alter the course of cement hydration reactions. Hydrolyses of heavy metals result in the reduction of $\mathrm{pH}$ and accelerate cement hydration. They may influence the formation and properties (structure and permeability) of the protective hydrated layer, and further influence the nucleation and growth of reaction products. The efficacy of cement-based solidification/stabilization can be improved by modifying cement phase compositions and controlling temperature, water/solid ratios, particle size, and other factors, that affect setting and strength development and long-term durability 
of solidified waste forms (Chen et al., 2009a; Habib et al., 2011). One factor that seems to have a large influence on the properties of the binder is the carbonation of Portland cement (Chen et al 2009b). McWhinney et al. $(1990,1993)$ noted that metals, such as $\mathrm{Ba}, \mathrm{Cr}, \mathrm{Pb}, \mathrm{Cd}$ and $\mathrm{Hg}$, promoted cement carbonation in the presence of $\mathrm{CO}_{2}$. Walton et al. (1997) found that nickel, cadmium, mercury, lead and cobalt exhibited higher leaching rates from carbonated waste forms compared to non-carbonated analogues. Chen et al. (2009b) demonstrated that the accelerated carbonation with a combination of dissolved $\mathrm{Na}_{2} \mathrm{CO}_{3}$ and gaseous $\mathrm{CO}_{2}$ can improve significantly compressive strength of solidified sediment containing mercury, lead, copper, nickel and zinc, by reducing porosity and consequently permeability that would, in principle, be desirable for a matrix used to encapsulate toxic wastes.

In some cases, a pre-treatment, to render such substances harmless, e.g., by adsorbent addition, is necessary (Chen et al., 2009a). Zhang et al. (2009) used a thiolfunctionalized zeolite as pre-treatment of the mercury waste before cement stabilization. The thiol-functionalized zeolite (TFZ) used in the study was obtained by grafting the thiol group (-SH) to the natural clinoptilolite zeolites. The mercury adsorption capacity is greatly enhanced upon thiol grafting and the maximum adsorption capacity is increased from $0.041 \mathrm{mmolHg} / \mathrm{g}$ to $0.445 \mathrm{mmolHg} / \mathrm{g}$. The optimum $\mathrm{pH}$ for the mercury stabilization using TFZ is around 5.0. The optimum TFZ dosage is about $5 \%$ and the optimum cement dosage is about $100 \%$. In the study of stabilization of the surrogates without interferences, mercury-loaded TFZ successfully passed the TCLP leaching test. Though $\mathrm{Cl}^{-}$and $\mathrm{PO}_{4}{ }^{3-}$ have a negative influence on mercury adsorption by TFZ, the Portland cement solidification of TFZ stabilized surrogates successfully passed the TCLP leaching test even in the presence of $\mathrm{Cl}^{-}$or $\mathrm{PO}_{4}{ }^{3-}$. The stabilization/solidification 
process using TFZ and Portland cement is an effective technology to treat and dispose of mercury-containing wastes. Other authors use a previous stabilization of the $\mathrm{Hg}$ with sulfur (see 2.1) followed by an encapsulation in cement matrixes (Svensson et al., 2007). After an initial period of 60 days, the leach rate was very low in all studied systems, including in some systems similar to the reference system containing $\mathrm{HgS}$ from the start. It was likely that a major fraction of the added mercury had been transformed to $\mathrm{HgS}$.

As an alternative to the S/S method employing cement, Zhuang et al. (2004) had reported the treatment of brine purification sludge (BPS) with ferric-lignin derivatives (FLD) and Portland cement (PC). They find that this treatment is an economical and simple process for the stabilization of BPS. FLD had demonstrated the capability to immobilize the leachable $\mathrm{Hg}$ contaminants through the strong bonding strength with Hg-contaminants in BPS. The FLD technology has provided an alternative solution for BPS treatment, which should be beneficial to the environmental protection. In addition, the application of FLD technology reduced the BPS treatment and disposal costs.

Cement (e.g. ordinary Portland cement) acting as the cementitious filler material is used for the encapsulation of elemental mercury. To improve the leaching properties, a previous stabilization step (amalgamation with $\mathrm{Cu}$ ) is carried out. Additional inorganic fillers can be added to this process as pulverized fuel ash, hydrate lime, finely divided silica, limestone flour and organic and inorganic fluidizing agent and especially blast furnace slag (BFS). The ratio of the inorganic filler to the cementitious filler material can be in the range of $3: 1 \mathrm{w} / \mathrm{w}$. The immobilized mercury shall be mixed Requirements 
for facilities and acceptance criteria for the disposal of metallic mercury in a ratio of 1:1 w/w with the filler material (US20080234529, 2008).

\subsubsection{Asphalt}

Asphalt micro-encapsulation can be used for encapsulating different wastes. For mercury containing waste, cold-mix asphalt seems to be more appropriate than hot-mix asphalt due to the possible volatilization of mercury (Randall and Chattopadhyay, 2004). The papers cited in the bibliography, use this kind of stabilization for low quantities of mercury, for example Cerkinkova et al. (2007).

\subsubsection{Polyester resins}

Polyester is a thermosetting resin that undergoes a chemical reaction to solidify. With this kind of encapsulation, waste loads of $50 \%$ have been reported but no information for the usability for metallic mercury is available (BiPro, 2010).

\section{Conclusions}

A huge number of researches have been carried out for the treatment of liquid mercury and mercury-containing wastes which is a consequence of the global concerns on mercury. Although it is difficult to considerer which is nowadays the best technology to be applied, because of the different chemical and physical characteristics and properties of the wastes to be treated, it seems that stabilization/solidification is one of the most effective and safest technologies. In the case of amalgamation, the obtained vapor 
pressure of amalgams is not as low as to consider it a valid method. In the case of heat treatment and vitrification, the major disadvantage is the high energy consumption, besides in the case of heat treatment, once recovered $\mathrm{Hg}^{0}$, it is necessary to undergo further treatment.

Within the different stabilization/solidification technologies it seems that the more mature one is SPSS, which provides final products with very scarce leachability of mercury and high durability. Nevertheless various processes should be scaled up to ensure that bench scale results are transferable to larger scale.

To define the best technologies for the treatment of mercury and mercury-containing wastes, in a global concept, might be quite improper, due to the different nature and physic-chemical characteristic of wastes. A proper evaluation of each individual case, which should include the environmental and the economical costs, along with the detailed study of the available technologies seems to be recommended. Thus, for example in the case of radioactive wastes containing $\mathrm{Hg}$, the application of vitrification or thermal treatment could be applicable, in spite of the high cost of these technologies.

\section{Acknowledgements}

Dr. O. Rodriguez thanks to CSIC (Spain) for the grant JAEDoc_09_00121 (FSE 20072013 program). 


\section{References}

BiPro (Beratungsgesellschaft für integrierte Problemlösungen), 2010. Requirements for facilities and acceptance criteria for the disposal of metallic mercury $(07.0307 / 2009 / 530302)$.

Busto, X. Cabrera, F.M.G. Tack, M.G. Verloo, 2011. Potential of thermal treatment for decontamination of mercury containing wastes from chlor-alkali industry. Y. J. Hazard. Mat. 186, 114-118.

Cerkinkova M., Vondruska, M., Bednarik, V., Pazdera, A., 2007. Stabilization/Solidification of munition destruction waste by asphalt emulsion, J. Hazard. Mat., 142, 222-226.

Chang, T.C., Yen, J.H., 2006. On-site mercury-contaminated soils remediation by using thermal desorption technology, J. Hazard. Mater. B128, 208-217.

Chang, T.C., You, S.J., Yu, B.S., Chen, C.M., Chiu, Y.C., 2009. Treating high-mercurycontaining lamps using full-scale thermal desorption technology, J. Hazard. Mat. 162, 967-972.

Chattopadhyay, S., Condit, W.E., 2002. Advances in Encapsulation Technologies for the Management of Mercury-Contaminated Hazardous Wastes. US EPA Technical Report, EPA/600/R-02/081. 
Chattopadhyay, S., 2003. Evaluation of chemically bonded phosphate ceramics for mercury stabilization of a mixed synthetic waste. http://www.epa.gov/nrmrl/pubs/600r03113/600r03113.pdf

Chen, Q.Y., Tyrer, M., Hills, C.D., Yang, X.M., Carey, P., 2009a. Immobilisation of heavy metal in cement-based solidification/stabilisation: A review, Waste Manag. 29, $390-403$.

Chen, Q.Y., Ke, Y., Zhang, L., Tyrer, M., Hills, C.D., Xue, G., 2009b. Application of accelerated carbonation with a combination of $\mathrm{Na}_{2} \mathrm{CO}_{3}$ and $\mathrm{CO}_{2}$ in cement-based solidification/stabilization of heavy metal-bearing sediment, Journal of Hazardous Materials 166, 421-427.

Clarkson, T.W., Marsh, D.O., 1982. Mercury toxicity in man, in: Prasad A.S. (Ed.), Clinical, Biochemical, and Nutritional Aspects of Trace Elements, vol. 6, Alan R. Liss, Inc., New York, pp. 549-568.

Clarkson, T.W., 1992. Mercury: major issues in environmental health, Environ. Health Perspect. 100, 31-38.

Comuzzi, C., Lesa, B., Aneggi, E., Dolcetti, G., Goi, D., 2011. Salt-assisted thermal desorption of mercury from contaminated dredging sludge, J. Hazard. Mat. in press. 
DE 102008006246, German Patent, 2009. Verfahren und Vorrichtung zur Herstellung von Quecksilberfluid zur anschließenden Entsorgung, DELA GmbH.

Dermont, G., Bergeron, M., Mercier, G., Richer-Laflèche, M., 2008. Soil washing for metal removal: A review of physical/chemical technologies and field applications, J. Hazar. Mat. 152, 1-31.

Directive 2000/60/EC of the European Parliament and of the Council of 23 October 2000 establishing a framework for Community action in the field of water policy. Official Journal L 327, 22/12/2000; 0001-0073.

Federal Remediation Technologies Reference Guide and Screening Manual, Version 4.0. 2001. Federal Remediation Technologies Roundtable. September 5. http://www.frtr.gov/matrix2/top_page.html

Fernández-Martínez, R., Loredo, L., Ordóñez, A., Rucandio, M.I., 2006. Physicochemical characterization and mercury speciation of particle-size soil fractions from an abandoned mining area in Mieres, Asturias (Spain). Environ. Pollut. 142, $217-$ 226.

Fitzgerald, W.F., Engstrom, D., Mason, R.P., Nater, E.A., 1998. The case for atmospheric mercury contamination in remote areas, Environ. Sci. Technol. 32, 1-6.

Fuhrmann M., Relamed D., Kalb P.D., Adams J.W., Milina L.W., 2002. Sulfur polymer solidification/stabilization of elemental mercury waste. Waste Manage. 22, 327-333. 
Huang, Y.T., Hseu, Z.Y., His, H.C., 2011. Influences of thermal decontamination on mercury removal, soil properties, and repartitioning of coexisting heavy metals, Chemosphere 84 (2011) 1244-1249.

Gray, J.E., 2003. Leaching, transport, and methylation of mercury in and around abandoned mercury mines in the Humboldt River basin and surrounding areas, Nevada. US Geol. Surv. Bull. 2210-C, 15 pp.

Gorin, A. H.; Leckey, J. H.; Nilf, L. E., 1994. Final disposal options for mercury/uranium mixed wastes from the oak ridge reservation. Oak Ridge Y-12 Plant,TN (United States), Report Y/DZ-1106.

GRS (Gesellschaft für Anlagenund Reaktorsicherheit mbH), 2009. Technologies for the stabilization of elemental mercury and mercury-containing wastes. GRS - 252; ISBN 978-3-939355-27-4.

Habib, M.A., Bahadur, N.M., Mahmood, A.J., Islam, M.A., 2011. Immobilization of heavy metals in cementitious matrices, J. Saudi Chem. Soc., in press.

Higueras, P., Oyarzun, R., Biester, H., Lillo, J., Lorenzo, S., 2003. A first insight into mercury distribution and speciation in soils from the Almadén mining district, Spain. J. Geochem. Explor. 80, 95-104. 
Huang, Y.T., Hseu, Z.Y, His, H.C., 2011, Influences of thermal decontamination on mercury removal, soil properties, and repartitioning of coexisting heavy metals, Chemosphere 84, 1244-1249.

Khan, F.I., Husain, T., Hejazi, R., 2004. An overview and analysis of site remediation technologies, J. Environ. Manage. 71, 95-122.

Land Disposal Restrictions Regulations for Mercury-Containing Non-wastewaters (http://www.epa.gov/osw/hazard/tsd/mercury/treatment.htm)

Lide, D.R. ed., CRC Handbook of Chemistry and Physics, Internet Version 2005, http://www.hbcpnetbase.com, CRC Press, Boca Raton, FL, 2005

Liu, Z., Qian, G., Zhou, J., Li, C., Xu, Y., Qin, Z., 2008. Improvement of ground granulated blast furnace slag on stabilization/solidification of simulated mercury-doped wastes in chemically bonded phosphate ceramics, J. Hazard. Mat. 157, 146-153.

López-Delgado, A., López, F.A., Alguacil, F.J., Padilla, I., Guerrero, A., 2012. A microencapsulation process of liquid mercury by sulfur polymer stabilization/solidification technology. Part I: characterization of materials, Rev. Metal. Madrid, 48(1).

López-Delgado, A., Guerrero, A., López, F.A., Pérez, C., Alguacil, F.J., 2012. A microencapsulation process of liquid mercury by sulfur polymer stabilization/solidification technology. Part II: durability of materials, Rev. Metal. Madrid, 48(1). 
López, F.A., Román, C.P., Padilla, I., López-Delgado, A., Alguacil, F.J., 2009a. The application of sulphur concrete to the stabilization of Hg-contaminated soil, 1st Spanish national conference on advances in materials recycling and eco-energy, Madrid.

López, F.A., Pérez, C., Guerrero, A., Goñi, S., Alguacil F.J., López-Delgado, A., 2009b. Stabilization of mercury by sulphur concrete: Study of the Durability of the Materials obtained, 1st Spanish National Conference on Advances in Materials Recycling and Eco-Energy, Madrid.

López, F.A., López-Delgado, A., Padilla, I., Tayibi, H., Alguacil, F.J., 2010. Formation of metacinnabar by milling of liquid mercury and elemental sulphur for long term mercury storage, Sci. Total Environ. 408, 4341-4345.

Mason, R.P., Fitzgerald, W.F., Morel, F.M.M., 1994. The biogeochemical cycling of elemental mercury: anthropogenic influences, Geochim. Cosmochim. Acta 58, 31913198.

Mason, R.P, Reinfelder, J.R., Morel, F.M.M., 1996. Uptake, toxicity, and trophic transfer of mercury in a coastal diatom, Environ. Sci. Technol. 30, 1835-1845.

Massachusetts Deparment of Environmental Protect (MADEP), 1996. Mercury: Forms, Fate \& Effects (Chapter 2) www.mass.gov/dep/toxics/stypes/hgch2.htm 
McWhinney, H.G., Cocke, D.L., Balke, K., Ortego, J.D., 1990. An investigation of mercury solidification and stabilization in Portland cement using X-ray photoelectron spectroscopy and energy dispersive spectroscopy, Cem. Concr. Res. 20, 79-91.

McWhinney, H.G., Cocke, D.L., 1993. Surface study of the chemistry of zinc, cadmium and mercury in Portland cement, Waste Manage. 13, 117-123.

Miretzky, P., Fernandez Cirelli, A., 2009. Hg(II) removal from water by chitosan and chitosan derivatives: A review, J. Hazard. Mat. 167, 10-23.

Navarro, A., Cañadas, I., Martinez, D., Rodriguez, J., Mendoza, J.L., 2009. Application of solar thermal desorption to remediation of mercury-contaminated soils, Sol. Energy $83,1405-1414$.

Navarro, A., Biester, H., Mendoza, J.L., Cardellach, E., 2006. Mercury speciation and mobilization in polluted soils of the Valle del Azogue $\mathrm{Hg}$ mine (SE, Spain). Environ. Geol. 49, 1089-1101.

P200930672/ES1641.553, 2009. López Gómez, F.A., López Delgado, A., Alguacil Priego, F.J., Alonso Gamez, M., Procedimiento de estabilización de mercurio liquido mediante cemento polimétrico de azufre, vía sulfuro de mercurio, CENIM-CSIC.

Piao, H., 2003. Stabilization of Mercury-containing Wastes Using Sulfide, Department of Civil and Environmental Engineering of the College of Engineering, University of Cincinnati. Ph.D. Thesis. 
Piao, H. and Bishop P.L., 2006. Stabilization of mercury-containing wastes using sulfides, Environ. Pollut. 139, 498-506.

Proposal for a Regulation of the European Parliament and the Council on the banning of exports and the safe storage of metallic mercury. COM/2006/636 final .26.10, 2006.

Qiu, G., Cabrera, J., Marshla, A., Cai, Y., 2006. Mercury characterization in a soil sample collected nearby the DOE Oak Ridge Reservation utilizing sequential extraction and thermal desorption method. Sci. Total Environ. 369, 384-392.

Randall, P., Chattopadhyay, S., 2004. Advances in encapsulation technologies for the management of mercury-contaminated hazardous wastes, J. Hazard. Mat. B114, 211223.

Regulation (EC) No 1102/2008 of the European Parliament and of the Council, OJ L 30414.11 .08 , of 22 October 2008 on the banning of exports of metallic mercury and certain mercury compounds and mixtures and the safe storage of metallic mercury.

Rytuba, J.J., 2003. Mercury from mineral deposits and potential environmental impact. Environ. Geol. 43, 326-338.

Sigel, A., Sigel, H., 1997. Metal Ions in Biological Systems. Mercury and Its Effects on Environment and Biology, vol. 34, Dekker, New York. 
Svensson, M., Allard, B., 2008. Leaching of mercury-containing cement monoliths aged for one year, Waste Manage. 28, 597-603.

Taube, F., Pommer, L., Larsson, T., Shchukarev, A., Nordin, A., 2008. Soil remediation —mercury speciation in soil and vapour phase during thermal treatment, Water Air Soil Pollut. 193, 155-163.

The Interstate Technology \& Regulatory Council. 1998. Technical Guidelines for OnSite Thermal Desorption of Solid Media and Low Level Mixed Waste Contaminated with Mercury and/or Hazardous Chlorinated Organics.

US20050089460, 2005. Tranquila, J.M., Method of removing mercury from mercury contaminated materials.

US20080234529, 2008. Chan, H.B., Hall, R., Treatment of elemental mercury, Moore \& Van Allen PLLC.

US5034054, 1991. Process for treating mercury in preparation for disposal. J.C. Woodward.

US5678234, 1997. Colombo, P., Kalb, P.D., Heiser, J.H., Process for the encapsulation and stabilization of radioactive, hazardous and mixed wastes, Associated Universites, Inc. 
US6399849, 2002. Kalb, P.D., Melamed, D., Patel, B.R., Fuhrmann, M., Treatment of mercury containing wastes, Brookhaven Science Associates LLC.

US6403044, 2002. Litz, J.E., Broderick, T., Steward, R.M., Method and apparatus for stabilizing liquid elemental mercury, ADA Technologies Inc.

US7560087B2, 2009. C. Riviere-Huc, V. Huc, E. Bosse, Method for stabilisation of metallic mercury using sulphur, Société des Techniques en Milieu Ionisant (STMI), Université Paris sud (Paris XI), Centre National de la Recherche Scientifique.

US7691361B1, 2010. Boyle, J.M., Lawrence, B.J., Schreffler, S.A., Method and apparatus for generating mercury (II) sulphide from elemental mercury, Bethlehem Apparatus Company Inc.

US7914757, 2011. Bonmann, C., Process and device for immobilizing mercury by producing crystalline mercury sulphide for subsequent disposal of mercury sulphide, DELA GmbH Recycling und Umwelttechnik.

U.S. Department of Energy (DOE). 1998. Innovative Technology Summary Report. Plasma Hearth Process at the Science and Technology Research (STAR) Center, Idaho Falls, Idaho. November. http://costperformance.org/pdf/itsr26.pdf.

US DOE, 1999. Stabilization using phosphate bonded ceramics salt containing mixed waste treatment. DOE/EM0487. http://www.p2pays.org/ref/13/12699.pdf 
U.S. DOE, 2002. Innovative Technology Summary Report: The SepraDyne ${ }^{\text {TM}}-$ Raduce System for Recovery of Mercury from Mixed Waste. September. DOE/EM-0633. http://apps.em.doe.gov/OST/pubs/itsrs/itsr2380.pdf.

U.S. EPA, 1996. Harbauer Soil Washing/Vacuum Distillation System. EPA - BMBF Bilateral SITE Demonstration. Innovative Technology Evaluation Report. August. http://www.epa.gov/ORD/SITE/Bilateral/harbauer.pdf.

U.S. EPA, 1997a. Mercury Study Report to Congress Volume III: Fate and Transport of Mercury in the Environment. EPA 452-R-97-005. http://www.epa.gov/ttn/oarpg/t3/reports/volume3.pdf.

U.S. EPA 1997b. Engineering Bulletin, Technology Alternatives for the Remediation of Soils Contaminated with Arsenic, Cadmium, Chromium, Mercury, and Lead. Cincinnati, $\quad$ OH. EPA-540-S-97-500. March. http://www.epa.gov/clariton/clhtml/pubtitleOSWER.html.

U.S. EPA, 2004. Minergy Corporation Glass Furnace Technology Evaluation Report. EPA/540/R-03/500. March. http://costperformance.org/pdf/20040702_353.pdf.

U.S. EPA, 2005. Great Lakes Pollution Prevention and Toxics Strategy. Background Information on Mercury Sources and Regulations. http://www.epa.gov/grtlakes/bnsdocs/mercsrce/merc_srce.html. 
U.S. EPA, 2007. Treatment Technologies for mercury in soil, waste and water. (542R07003)

U.S. EPA, 2011. Mercury. http://www.epa.gov/mercury/ (access 19/08/11)

U.S. EPA and Environment Canada, 1999. Update: Binational Toxics Strategy Mercury Sources and Regulations. http://www.epa.gov/bns/mercury/stephg.html.

Wagh, A.S., Singh, D., Jeong, S.Y., 2000. Chemically bonded phosphate ceramics for stabilization and solidification of mixed waste. Environmental Protection Agency's Workshop on Mercury Products, Processes, Waste, and the Environment: Eliminating, Reducing and Managing Risks, Baltimore, MD, March 22-23, 2000. http://www.anl.gov/techtransfer/Available_Technologies/Material_Science/Ceramicrete /wagh-mercury.pdf

Wagner-Döbler, I., 2003. Pilot plant for bioremediation of mercury-containing industrial wastewater, Appl. Microbiol. Biotechnol. 62, 124-133.

Walton, J.C., Bin-Shafique, S., Smith, R.W., Gutierrez, N., Tarquin, A., 1997. The role of carbonation in transient leaching of cementitious waste forms, Environ. Sci. Technol. $31,2345-2349$.

Washburn, C., Eldan H, 2003. Mercury Retorts for the Processing of Precious Metals and Hazardous Wastes. JOM 55, 45-50. 
www.handbookofmineralogy.org Access August 2011.

Woodward, , 1991. Process for treating mercury in preparation for disposal. Patent US 5034054

Zhang, X.Y., Wang, Q.C., Zhang, S.Q., Sun, X.J., Zhang, Z.S., 2009. Stabilization/solidification (S/S) of mercury-contaminated hazardous wastes using thiolfunctionalized zeolite and Portland cement, J. Hazard. Mat. 168, 1575-1580.

Zhao, P., Guo, X., Zheng, C., 2010. Removal of elemental mercury by iodine-modified rice husk ash sorbents, J. Environ. Sci., 22, 1629-1636.

Zhuang, J.M., Loa, T., Walsh, T., Lam, T., 2004. Stabilization of high mercury contaminated brine purification sludge, J. Hazard. Mat. B113, 157-164. 